\title{
ENTERING AND STAYING IN THE SCHOOL OF HUMANITIES OF THE UNIVERSITY OF MAR DEL PLATA. ACADEMIC HOMOGENIZATION OR HIDDEN EXCLUSION?
}

\author{
Blanc, María Inés, \\ Profesora especialista en docencia universitaria National University of Mar \\ del Plata \\ Pervieux, Laura Alicia, \\ Profesora en Bibliotecología y Documentación National University of Mar \\ del Plata \\ Regueira, Ana Lía,
}

Master of Arts in English Language Teaching National University of Mar del Plata

Zuppa, Silvia Amanda,

Profesora Adjunta de Didáctica Especial y Práctica Docente National

University of Mar del Plata

\begin{abstract}
This work forms part of a larger project that proposes the reformulation of content structures and pedagogic practices at the School of Humanities of the University of Mar del Plata. The project has a twofold objective: To improve the retention rate of $1^{\text {st }}$ year students by implementing actions related to the disciplinary and institutional areas and by developing mechanisms that would help the undergraduates in the process of "becoming college students"; and to strengthen the links between secondary and higher education in order to improve the students' possibilities of accessing and remaining in university. This presentation reports the work done so far in relation to the first objective.

The different courses of studies offered by the School of Humanities show a high rate of dropouts among $1^{\text {st }}$ year students. In a survey carried out among students and teachers the main reason for these dropouts was reported to be the lack of academic training with which students enter university.

This paper will address the reasons that generate a kind of silent violence that is manifested in the difficulties students have in getting adapted to the university context, both socially and academically, and which derives in exclusion and self-exclusion when the students find too many obstacles to
\end{abstract}


pursue their studies and, therefore, drop out. From a social perspective, these students belong to low-income groups; they come from marginal secondary schools and have parents who lack a university education. Our aim is to exchange viewpoints and experiences with colleagues from different universities on the different issues that relate to this sort of hidden exclusion.

Keywords: Entering - Staying - Inclusion - Academic exclusion - Silent violence

Becoming a college student means getting integrated to a place where learning takes place. College students have to read a lot, think, discuss, question, make mistakes and acknowledge them, write and talk. Besides, they need to develop an ability to deal with the complexity of educational structures, make informed decisions and manage their educational careers. All this generates a strong burden on Argentine youngsters who enter university with scarce abilities to cope with the demands of higher studies, probably because of the way education is conceived and, consequently, delivered in our high school system. This paper addresses these issues on the basis of a project carried out at the School of Humanities of the National University of Mar del Plata.

This work forms part of a larger project that proposes the reformulation of content structures and pedagogic practices at the School of Humanities, and develops from one of the tasks being carried at the moment in the framework of the Programme for the Support of the Human Sciences, derived from an agreement between the Ministry of Education and the University of Mar del Plata. The overall project has a twofold objective: to improve the retention rate of $1^{\text {st }}$ year students by implementing actions related to the disciplinary and institutional areas and by developing mechanisms that would help the undergraduates in the process of "becoming college students"; and to strengthen the links between secondary and higher education in order to improve the students' possibilities of accessing to and staying in university. In this paper, the focus will be on a preliminary evaluation of the situation of $1^{\text {st }}$ year students of the different courses of study offered at the School of Humanities.

According to María Cristina Rinaudo many specialists agree that university graduates should be able to:

- Understand complex concepts

- Use knowledge (ideas, theories, etc.) creatively

- Evaluate critically what they read

- Write and talk clearly 
- Take responsibility for on-going learning ${ }^{4}$

What should students entering university be able to do? How deep is the gap between what students bring from secondary school and what they need to know and manage by the end of their university studies? How does social and family background affect the possibilities of success or failure? Why do so many students fail to succeed in their attempts to become university students? Why do so many students drop out in $1^{\text {st }}$ year? To what extent are universities responsible for these dropouts?

In the last years, there has been a strong debate in Argentine educational circles on the reasons that cause a high number of dropouts in the first year of university and the possibilities that universities have of dealing with this and finding a solution. According to Paula Carlino, "learning at university is not a guaranteed achievement. It depends on the interaction between the students, the teachers and the institution. It depends on what the learner does, but also on the conditions we offer as teachers. In this light, the responsibility of students' success is shared by the teachers and the institutions, and the students themselves." (Authors' translation). ${ }^{5}$

In 2005, María del Carmen Parrino claimed that the number of dropouts at university level reached $\% 60$, and also that, according to various studies, the main reasons were related to personal issues (\% 47). Financial reasons reached \% 20, within which \% 39 were related to the need of the students to start working, \% 27 to a decrease in the family income, and \% 20 to the effects produced by the cost of the studies on the family budget. Also, academic reasons were mentioned ( $\% 20)$, while $\% 12$ corresponds to problems related to vocation. ${ }^{6}$

It is also worth mentioning that in 2001 the National Census showed that \% 3, 14 of the country population graduated from an Argentine university, a percentage that is similar to that of the number of illiterate people in the country.

At present, Argentina is not the only country where the rate of dropouts at university level has increased in the last years. In Spain, it ranges between \% 30 and \% 50 and these numbers are similar in other European countries, namely France and Austria, and in the United States. In other

\footnotetext{
${ }^{4}$ Rinaudo, M.C. (2010) Para aprender en la universidad. Córdoba, Ediciones UBP y Encuentro Grupo Editor. Pág. 21 y 22.

${ }^{5}$ Carlino, P. (2009) Escribir, leer y aprender en la universidad: Una introducción a la alfabetización académica. Buenos Aires, Fondo de Cultura Económica. Pág. 10 ${ }^{6}$ Padrino, MC (2005) V Coloquio Internacional sobre Gestión Universitaria en América del Sur. Poder, Gobierno y Estrategias en las Universidades de América del Sur. Aristas de de la Problemática de la Deserción Universitaria. Mar del Plata, Argentina del 8 al 10 de diciembre.
} 
European countries, however, the rates are much lower, such as in Finland and Switzerland, according to a report published by Margarita Latieza, professor of the University of Granada. ${ }^{7}$

The numbers for Argentina illustrate that there is a problem of interrelationship among the different levels of the educational system, since high school students do not seem to be acquiring the competencies needed for higher education, and also that there should be a reformulation of educational and institutional policies that will guarantee the entrance and also the stay of students at university.

This situation is also observed at the University of Mar del Plata and this Project intends to delve into the problems from different perspectives. So far we have gathered some baseline data which will support future actions. On the one hand, we carried out a survey among $1^{\text {st }}$. year students and teachers to try to understand their perceptions of these issues. On the other, we analysed the programmes of $1^{\text {st }}$. year courses, in an attempt to see how the students' and teachers' concerns identified in the survey are addressed in the designs and plans of the courses.

In the following sections of this paper, the results of the survey and the analyses of the courses programmes are reported. Finally, some conclusions and insights got from the analysis are discussed.

\section{The survey}

In order to find out which are the main reasons that $1^{\text {st }}$ year students and teachers at the School of Humanities identify as being the causes of difficulties during the first year of studies, we carried out a survey which offered the following results.

\footnotetext{
${ }^{7}$ Para ampliar, ver Latieza, M (2010) La deserción universitaria, España, Siglo XXI, Pág. 10
} 


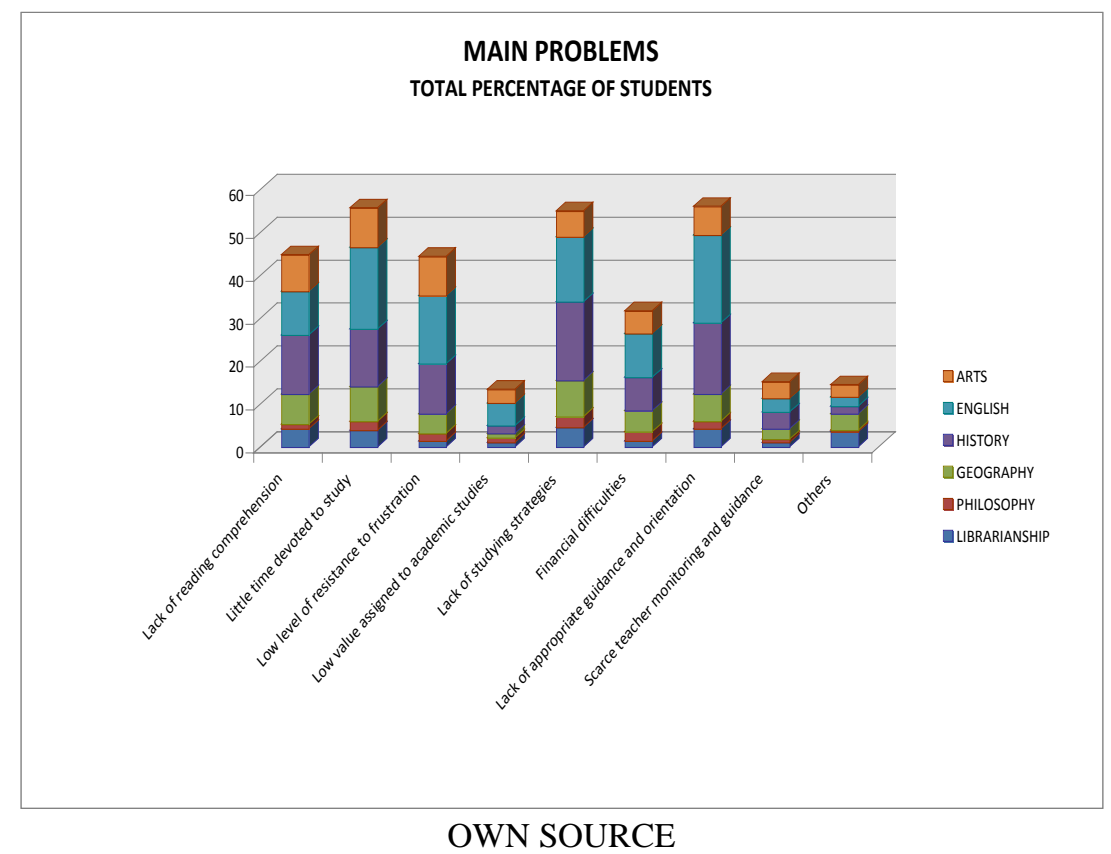

\section{Each column represents the total number of students that answered the survey.}

Among the 248 students who answered the survey, \% 55.9 believes that the problem is that they lack appropriate guidance to deal with the new demands and the academic environment; while \% 55.7 claims that they do not devote enough time to study. \% 55 thinks that they lack the right studying strategies and \% 44.7 that the problem is reading comprehension. \% 44.4 claims that the main difficulty is their low level of resistance to frustration.

Twenty two teachers from the different courses of study participated in the survey. The first question of the survey, which is the one that provides information about the causes of problems in $1^{\text {st }}$ year, was the same as the one in the students' survey. The teachers' answers are presented in the following diagram. 


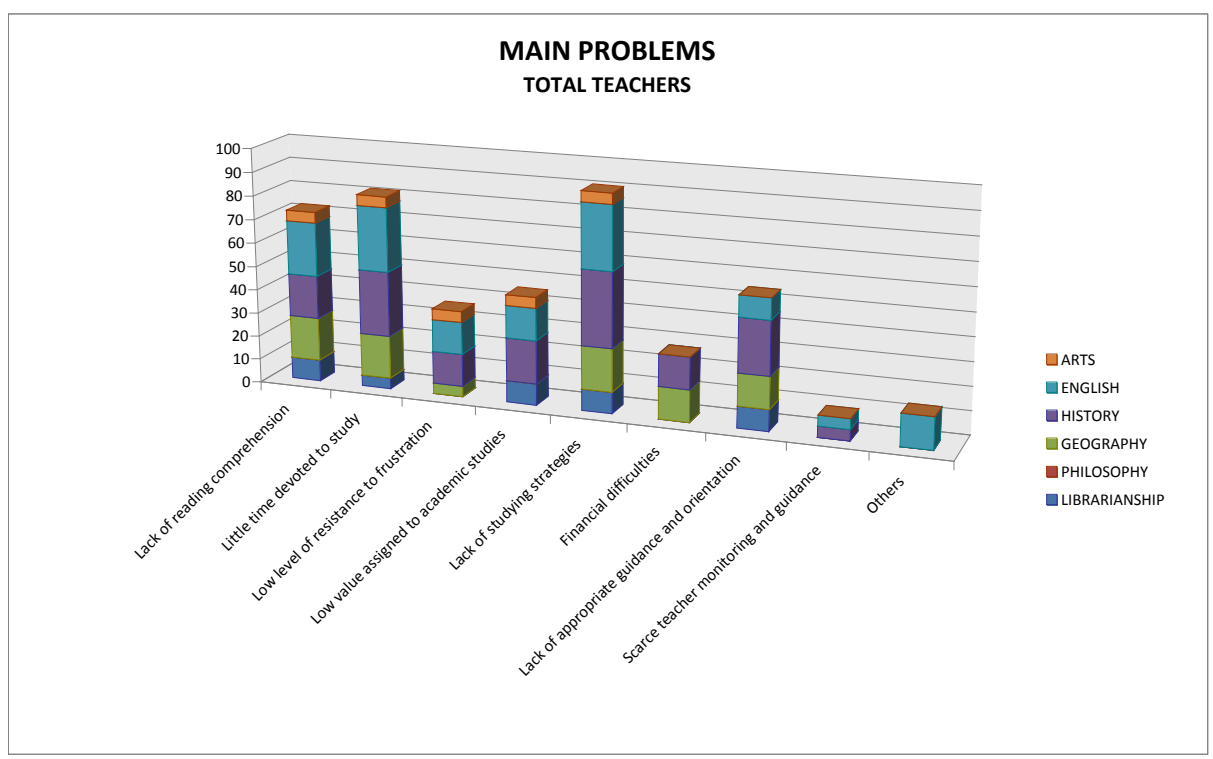

OWN SOURCE

The results show the following order of priorities for the teachers:

- Lack of studying strategies: \% 91.9

- Little time devoted to study: \% 81.8

- Lack of reading comprehension: \% 72.7

- Lack of appropriate guidance to deal with the new university demands and the academic environment: \% 54.5

- Lack of value assigned to academic studies: \% 45.4

Based on the insights got from the results of the survey, we decided to see what is being done in $1^{\text {st }}$ year courses in relation to the students' problems, because we understood that, if the teachers had identified the same problems, they were probably doing something in their courses to help the students overcome some of their difficulties. Some of the teachers who answered the survey expressed their willingness to participate in some kind of programme or project to deal with these matters. We decided to have a look the $1^{\text {st }}$ year programmes to find some information related to the issues at stake.

\section{Analysis of course programmes}

In an attempt to understand the several issues that appear to be related to the difficulties that students face during $1^{\text {st }}$ year at university, we decided to analyse the syllabuses of the core $1^{\text {st }}$ year courses of the following courses of study: History, Geography, Librarianship, and English. The aim was to get some information about the courses with the higher number of students in $1^{\text {st }}$ 
year and to have enough data to create better tools to improve the pedagogic actions to be taken to help students stay at university and succeed in $1^{\text {st }}$ year.

The number of students that enrolled for each course and the number of students that finished the courses are presented in the following chart:

\begin{tabular}{|c|c|c|c|}
\hline$\frac{\text { Courses of Study at }}{\text { the UNMDP }}$ & $\frac{1^{\text {st }} \text { year core }}{\text { courses }}$ & $\begin{array}{l}\text { Students enrolled } \\
\text { in the course }\end{array}$ & $\begin{array}{c}\text { Students who } \\
\text { finished the course }\end{array}$ \\
\hline HISTORY & $\begin{array}{c}\text { Introduction to } \\
\text { Historical Practice }\end{array}$ & 197 & $\begin{array}{c}88 \\
\% 44,67\end{array}$ \\
\hline GEOGRAPHY & $\begin{array}{c}\text { Introduction to } \\
\text { Geography }\end{array}$ & 102 & $\begin{array}{c}44 \\
\% 43,13 \\
\end{array}$ \\
\hline LIBRARIANSHIP & $\begin{array}{l}\text { Introduction to } \\
\text { Information } \\
\text { Sciences }\end{array}$ & 77 & $\begin{array}{c}32 \\
\% 41,55\end{array}$ \\
\hline ENGLISH & Written Discourse I & 52 & $\begin{array}{c}33 \\
\% 63,46\end{array}$ \\
\hline
\end{tabular}

OWN SOURCE

These numbers show that there are a lot of students who register for the $1^{\text {st }}$ year courses who cannot get to the end of them, either because they fail the exams or because they decide to drop out for other reasons.

In the analysis of the syllabuses, we tried to see if the problems identified in the survey, both by students and teachers, were in some way being considered in the objectives, contents or activities planned for the different courses. The analysis was based on:

- The objectives that relate to the problems highlighted in the survey, since it is possible to help students overcome their difficulties and succeed in $1^{\text {st }}$ year if their concerns and weaknesses are appropriately addressed.

- The objectives and activities that contribute to critical thinking. Critical thinking is a crucial competence students need to develop at university level, and it is important to plan actions to assist them gradually. Sometimes university teachers take critical thinking abilities for granted and, therefore, do not include them as part of the objectives for their courses.

- The integration of content and competencies. Discipline-specific competencies should be integrated to the teaching of content to guarantee effective learning.

- The relationship between objectives and evaluation. Many times evaluations assess competencies which are not taught during a course, but which are assumed to be part of what the students should already know, and, therefore, are neither stated as part of the course objectives, nor taught during the course. This is a serious drawback for students who, after making a great effort to comply with the courses' requirements, are unable to achieve the expected standards. 
The analysis done showed that many of the problems identified in the survey are only partially considered in the courses offered in $1^{\text {st }}$ year. All the programmes include at least one objective related to critical thinking abilities, as well as one or two related to reading comprehension abilities, although it does not become clear how these objectives are expected to be achieved. There are no objectives that clearly refer to studying or learning strategies, but in all the cases the description of learning activities shows an integration of discipline-specific competencies to the teaching of content. As regards evaluation, only one of the programmes specifies criteria for assessing students, while the others only mention instruments and dates.

Through the analysis of the programmes it is not possible to see if the teachers acknowledge the specific problems that $1^{\text {st }}$ year students face at present. If we consider the information gathered together with the number of students who successfully pass the courses, we see a need for specific actions that address the issues discussed.

\section{Lines of Action}

Young people experience a sort of silent violence as they face failure at university, when they cannot understand what they read or cannot participate in a lesson. Very often, university teachers blame the high school system for the students' poor academic abilities. This combination of students who are academically illiterate and cannot cope with the demands of university life, and teachers who disclaim responsibility for what was not done before and for what is not done at university, derives in exclusion from the educational system.

The notion of silent violence has been taken from Luis Correa Aydo, who uses it to describe processes which have a strong impact on young people's subjectivity, but which are not perceived by the common observer. The term refers not only to a kind of internalized violence, but also to the reflection of it in the acts and productions of young people who are not, or do not seem to be, violent. Aydo claims that we are usually concerned with a kind of violence that is "noisy", that can be heard and seen, and that is so concrete that leaves a trail on bodies and objects, but in the case of silent violence he is extending the meaning of the notion to a symbolic level. ${ }^{8}$

The work done in the framework of this project has led us to reflect upon how silent violence and, therefore, exclusion, affect the lives of our students at the School of Humanities of the University of Mar del Plata. In an attempt to start working towards a solution to one of the most salient

\footnotetext{
${ }^{8}$ Correa Aydo, L. (S/F) Violencia silenciosa en el proceso adolescente. Biblioteca On line. Asociación Psicoanálisis del Uruguay. Pag. 2 http://www.apuruguay.org/portada_biblioteca
} 
problems identified by students and teachers, namely students' lack of academic preparation for coping with the complexities of university studies, we propose to offer an academic literacy course to $1^{\text {st }}$ year students. The aim is to improve the students' possibilities of finishing 1st year successfully and pursuing their objective of getting a university degree and becoming competent professionals.

To become academically literate, a person has to familiarize himself with the levels of communication that exist within all the areas of his academic environment. In higher education, academic literacy refers to the notions and strategies needed to participate in a specific discipline's discursive culture, as well as the activities of production and analysis of texts required to study at university. (Carlino, Paula, 2009)

Together with a course on academic literacy, new strategies and actions should be implemented in the different courses, especially in $1^{\text {st }}$ year, which would assist students and gradually involve them in the analysis and production of disciplinary texts. Also, a workshop for teachers at university, where the results of this work and other experiences are shared, may help them acknowledge the silent violence that students face in their attempts to become university students.

\section{Conclusions and final reflections}

Numerous investigations report on the large number of dropouts in $1^{\text {st }}$ year in Argentine universities. The student who reads but cannot understand, the one who feels himself excluded from the university environment because he cannot understand its dynamics, the one who feels that the teachers do not care about him, the one who faces financial troubles and cannot devote enough time to study because he needs to work, that is the student who suffers the consequences of silent violence.

If we consider the perceptions that our students have in relation to failure in their studies, i.e. lack of appropriate guidance to deal with the university demands and the academic environment, little time devoted to study, scarce studying strategies, lack of reading comprehension abilities, and lack of value assigned to academic studies, we can understand that there exists a component of the university environment that excludes them.

We observe a situation of marginalization of the more vulnerable groups of our society that seems to be inherent to university life. Let us have a look at each of the issues identified in our survey:

- As regards the lack of appropriate guidance to deal with the new university demands and the academic environment, there are no mechanisms, such as tutorials, that may assist students in the process of becoming university students, and the characteristics derived from the socio-economic conditions generate feelings of frustration. Paper work, registration in 
different offices or on-line, medical check-ups, etc. may result a true challenge for the $1^{\text {st }}$ year student. For those students from families with little experience of university education, it can be difficult to adapt to the new institutional context, and feelings of frustration and powerlessness on the part of the students may derive in self-exclusion. "Education has been subject to a process of marketization in which knowledgeable consumers with spending power are advantaged while others can be marginalized." (Furlong 2009).

- The amount of time devoted to study may be associated to the characteristics of the present state high school system. The standards of public education in Argentina have decreased dramatically in the last years, and the consequences can be clearly observed when students finish high school and enter university. It is during the last years of secondary education when students are supposed to learn how to handle study time appropriately, and to develop the studying and learning strategies necessary to understand different types of texts. Unfortunately, once students enter university, they are on their own to solve their lack of appropriate preparation for what they have to face.

- As regards the lack of value assigned to academic studies, it can be argued that, since many times teachers hold low expectations about the possibilities of success of students who belong to lower class families, those students develop an image of themselves that responds to their teachers' expectations. Like in a vicious circle, when teachers have no faith in their students' chances of success, students do not see themselves as capable of pursuing higher studies, and, consequently, assign little value to what university offers to them. On top of this, there seems to be a general lack of tolerance in certain university circles where, according to Silvia Rivera and Alejandro Margetic ${ }^{9}$ some teachers see themselves as a sort of scientific aristocracy, a circle of experts that requires of these young new students an excessive epistemological precision that confuses them and "forces" them into self-exclusion. Students feel that they are unable to achieve the type of erudition and formalism characteristic of hegemonic knowledge, and, therefore, may not regard education as a worthwhile endeavour.

We are clearly referring to hidden exclusion when the standards for evaluation are too high for students whose social and academic background does not allow them to cope with the demands of higher education. This hidden exclusion is in fact the result of the inability of university teachers and institutions to adapt to the situation and do what is needed to help students achieve the objectives of higher education. In the name of

\footnotetext{
${ }^{9}$ Rivera, S. y Margetic, A (2005) La intolerancia epistemológica como forma de exclusión del saber. Buenos Aires, Universidad de Lanús
} 
homogenization and high standards, universities ignore their responsibility and abandon those students with poor educational skills who are unable to participate in the academic activities taken for granted in university circles. Exclusion is legitimized by those who claim that it is necessary to give everyone the same, and do not take into account that each student is unique and has the potential of achieving the goals of higher education working from his or her own capacities.

It is not surprising that in certain disciplines, such as social work, the processes of marginalization and exclusion have become a central issue and that in some Canadian universities core courses are offered on Diversity and Social Justice ${ }^{10}$, in an attempt to generate empathy for the social differences that cause exclusion and inequity. Some of these processes have historical roots inherent to some cultures, while others are the result of globalization and the increasing search for dignified work that has generated the major migratory process ever seen on earth.

Many authors have worked on this phenomenon of marginalization of young people from educational systems as a process that has developed in our societies for different reasons. Andy Furlong claims that marginalization presents different characteristics in each country, but that immigrant groups are the ones that usually find more difficulties. In our city, foreign immigration is not strong, with the exception of Bolivian immigrants who are not represented yet at university. However, social exclusion can be observed in everyday life as a by-product of the neoliberal economic policies that in the last twenty years have transformed our society. On the other hand, in spite of the claims of different governments in recent years of having increased the number of years of compulsory schooling, arguing for equity and social support, this has in no way put an end to the problem of school dropouts in the country.

Our university is a representative part of the social structure of our country, and it is important to understand that generating the means to promote inclusion can make a crucial difference. Probably, if college students were considered as adults who learn and can contribute to the development of knowledge, it would be possible to work on their unique social realities and share a dialogue on the marginalization and exclusion processes from the students' own perspective. By working on critical and reflective thinking strategies, and by encouraging a culture of dialogue among students and teachers to explore multiple perspectives and solutions, without aiming at the identification of one single truth, it would be possible

\footnotetext{
${ }^{10}$ Bhuyan Rupaleem (2010) Social Exclusión, Marginalización \&Resistance, University of Toronto. On line noviembre 2010 http://technologiesofresistance.wordpress.com/
} 
to have student-friendly universities that generate knowledge useful to solve local problems and to improve the standards of living of the whole society.

\section{Bibliography:}

Bhuyan, R. (2010) Social Exclusion,Marginalization \& Resistance University of Toronto. http://technologiesofresistance.wordpress.com/

Carlino, P. (2009) Escribir, leer y aprender en la universidad: Una introducción a la alfabetización académica. Buenos Aires, Fondo de Cultura Económica.

Correa Aydo, L. (S/F) Violencia silenciosa en el proceso adolescente. Biblioteca On line. Asociación Psicoanálisis del Uruguay. Pag. 2 http://www.apuruguay.org/portada_biblioteca

Furlong, A (2009) Marginalized youth in education: Social and cultural dimensions of exclusión.Toronto, Marginalized and Contemporary Educational Contexts Conference. On line: http://www.chsrgevents.ca/shared/PDFs/Andy_Furlong_paper_May_2009.p $\mathrm{df}$

Rinaudo, M.C. (2010) Para aprender en la universidad. Córdoba, Ediciones UBP y Encuentro Grupo Editor.

Rivera, S. y Margetic, A (2005) La intolerancia epistemológica como forma de exclusión del saber. Buenos Aires, Universidad de Lanas.

Reynaga, G. (2010) Formas de Exclusión social en la la UNSCH y sus implicancias en el desarrollo integral de los estudiantes. http://www.unsch.edu.pe/portal/oficinas/investigaciones/revista\%202010.pdf \#page=94http://autonomiayemancipacion.org/Biblioteca/D4/Epistemologia\% 20\%20Silvia\%20Rivera\%20Cusicanqui\%20y\%20Alejandro\%20Margetic.pf 